\title{
Impact assessment of log skidding on soil condition of skid roads during ground-based logging in a plantation forest in Istanbul, Turkey
}

\author{
Evaluación del impacto de la vía de saca durante cosechas forestales \\ a nivel de suelo en una plantación en Estambul, Turquía
}

\author{
Tolga Ozturk ${ }^{\text {a*, Orhan Sevgi }}{ }^{\mathrm{b}}$, Abdullah E Akay ${ }^{\mathrm{c}}$ \\ *Corresponding author: a Istanbul University, Faculty of Forestry, Department of Forest Construction and, \\ Transportation, 34473, Bahcekoy, Istanbul, Turkey, phone: +905327147456, tozturk@istanbul.edu.tr \\ b Istanbul University, Faculty of Forestry, Department of Soil Science and Ecology, Istanbul, Turkey.

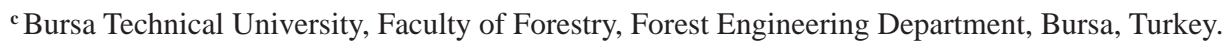

\begin{abstract}
SUMMARY
Ground-based logging operation is potentially one of the major soil-disturbing activities that cause soil displacement, rutting depth and soil compaction. Thus, logging operations should be carefully planned considering the factors that influence soil disturbance. In this study, soil displacement and rutting on the skid roads caused by a farm tractor during a logging operation were investigated in maritime pine (Pinus pinaster) plantation forest of Istanbul, Turkey. After each tractor pass, field measurements were performed on the selected cross sections that were established at $15 \mathrm{~m}$ intervals along a designated skid road. Soil disturbance caused by both rubber-tires and skidded logs was considered in this study. It was found that the average volume of soil displacement was $0.060 \mathrm{~m}^{2} \mathrm{~m}^{-1}$ along skid road. It was also found that the rut depth on skid road became significant after $5^{\text {th }}, 10^{\text {th }}, 15^{\text {th }}, 20^{\text {th }}$ and $30^{\text {th }}$ passes, reaching an average of 4.0 , 7.2, 8.7, 9.8 and $10.5 \mathrm{~cm}$, respectively. Results indicated that soil displacement and rut depth increased as the number of tractor passes increased.
\end{abstract}

Key words: ground-based logging, skid roads, soil displacement, rut depth.

\section{RESUMEN}

Las cosechas forestales a nivel de suelo son potencialmente una de las actividades que más daña al suelo, debido al desplazamiento y compactación producida por la maquinaria que se utiliza. Por lo tanto, las operaciones de extracción deben ser planificadas cuidadosamente teniendo en cuenta de los factores que influyen en la alteración del suelo. En este estudio, el desplazamiento del suelo y la formación de huellas en los caminos de arrastre causado por un tractor con ruedas de goma durante una operación cosecha se investigaron en una plantación de pino rodeno (o pino marítimo) (Pinus pinaster) en Estambul, Turquía. Después de cada pasada del tractor, se realizaron mediciones de campo en secciones transversales seleccionadas y establecidas en intervalos varios (10 m, 15 m, y 20 m) a lo largo de una vía de arrastre designada. La perturbación del suelo causada por los neumáticos de goma y el arrastre producido por los troncos al deslizarse fueron considerados en este estudio. Se encontró que el volumen medio del desplazamiento del suelo fue de $0,060 \mathrm{~m}^{3}$ por metro a lo largo de la vía de arrastre. También se encontró que la profundidad de la huella en la vía de arrastre empezó a ser significativa después de 5, 10, 15, 20 y 30 pasadas, alcanzando un promedio de 4,0, 7,2, 8,7, 9.8, y 10,5 cm, respectivamente. Los resultados indicaron que el desplazamiento del suelo y la profundidad de los surcos aumentaron a medida que las pasadas de tractor incrementaban.

Palabras clave: registro basado en tierra, caminos de arrastre, desplazamiento del suelo, profundidad de la huella.

\section{INTRODUCTION}

The extraction of wood-based forest products using mechanized systems can be a very difficult and costly activity, especially on mountainous regions. Besides, inadequately planned mechanized harvesting operations may cause serious damages on forest soil. Thus, all phases of wood extraction require careful consideration not only to minimize cost but also to reduce the negative impacts on forest soil. These soil disturbances are defined as rutting, soil displacement and soil loss.

Soil disturbance can be described as changes in the forest soil properties. Forest harvesting operations have high potentials for soil disturbances since heavy forestry machines cause soil compaction due to exerted normal pressure, shear stress and vibrations (Ampoorter et al. 2007, Jamshidi et al. 2008, Labelle and Jaeger 2011). The impacts on the physical properties of the soil reduce the soil air 
capacity (Schnurr et al. 2006), decrease soil infiltration (Ares et al. 2005) and reduce root growth (Jacobsen and Greacen 1985).

The impact of harvesting operations on forest soils can be categorized as soil compaction, lateral soil displacement, soil puddling and rutting (Majnounian and Jourgholami 2013). Skidders, tractors and other machines used in harvesting operations may affect forest soils considerably, mainly depending on terrain conditions, soil characteristics, soil moisture content and vehicle types (Akay et al. 2007). Besides, the gross weight of the vehicle, tire size and air pressure in the tires, travel speeds and the number of passes are the operational factors that affect the severity of soil compaction (Greene and Stuart 1985, Susnjar et al. 2006). Major soil disturbance usually occurs during the first passes of machinery and increases with the number of passes (Gayoso and Iroume 1991).

Operation period and selected machinery can make a big difference for protecting the soil from potential damages (Sutherland 2003). During periods when soils are wet, heavy harvesting machines with rubber-tires generate deep ruts over forest soil, which lead to several problems such as excessive delays in operations, serious impacts on physical properties of forest soil and damages on tree roots (Akay and Erdas 2007). Rutting occurs when soil strength is not sufficient to support the applied load from vehicle traffic (Lotfalian and Parsakhoo 2009).

In mechanized ground-based harvesting systems, the forest products are generally transported from stump to the landing areas by tractors. In Turkey, farm tractors equipped with winch are widely used for skidding operations in mountainous regions. The main aims of this study were: (1) to investigate soil displacement and rutting on the skid road by a farm tractor during a skidding operation in maritime pine (Pinus pinaster Ait.) plantation forest, and (2) to evaluate the changes among soil properties such as weight, texture, $\mathrm{pH}$, etc. on the skid road and the forest ground.

In relation to the aims, the specific hypotheses of the study are: 1) Ho: The soil displacement and rutting on the skid road have no variation in skidding operations by a farm tractor. 2) Ho: The soil properties on the skid road and the forest ground have no effect after skidding operations.

\section{METHODS}

Study area. The study area was located in Sile Forest Administration in northern Turkey. The general location of the study area is $41^{\circ} 12^{\prime} \mathrm{N}$ latitude and $29^{\circ} 24^{\prime} \mathrm{E}$ longitude (figure 1). The research was carried out at compartment number 37 in Sahilkoy forest management unit in August

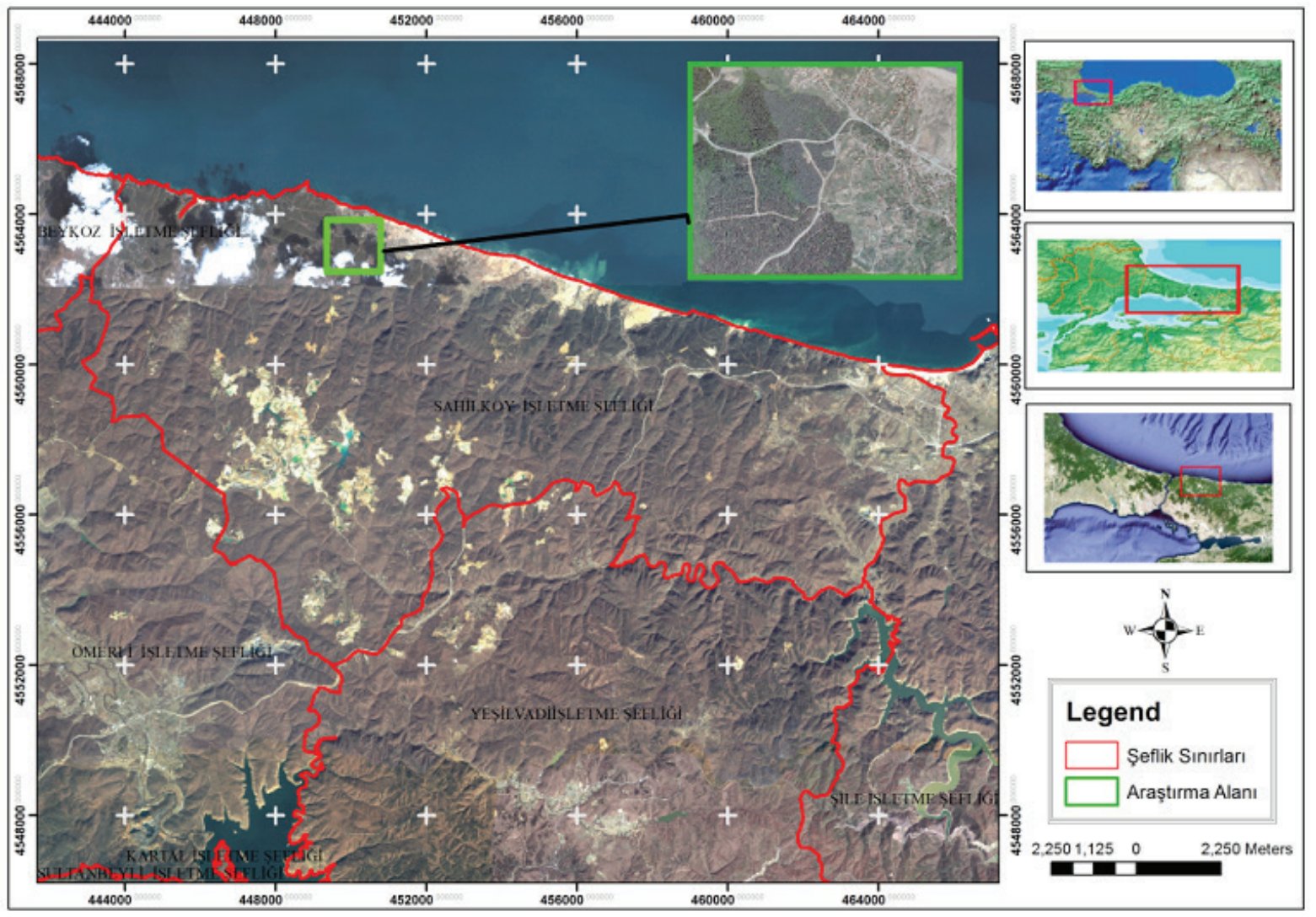

Figure 1. The location of Sile Forest Administration in northern Turkey.

Locación del bosque de Sile Bosque en el norte de Turquía. 
2013. The study area mainly lies on the northern aspect with altitude ranging between $250 \mathrm{~m}$ and $300 \mathrm{~m}$ above the sea level. The average monthly total rainfall for June, July, August in this region was $35.0,31.6$ and $40.7 \mathrm{~kg} \mathrm{~m}^{-2}$, respectively. The study area covered 3,000 hectares of a 25 year-old plantation of the maritime pine. The average tree diameter was $32 \mathrm{~cm}$, average tree height was $18 \mathrm{~m}$ and stand density has been measured to be 165 trees ha- ${ }^{-1}$. The maritime pine is a fast growing tree and its commercial value is high in Turkey. The plantation is harvested in rotation usually for every 25-30 years. Soil type is sandy soil in this region. The soil type of research area is cambisols combine soils according to the WRB soil classification system. This soil type was named Brown Forest Soils according to US systems. This soil is classified as Inceptisols according to American Soil Taxonomy.

Cutting method used in the study area. Skidding operation was performed by a farm tractor on the skid road. During skidding, one end of the load is lifted clear from the ground and set on the back of the tractor while the other end is skidded on the skid road. The skidding direction along the skid road was upward. An effort was made to choose a skid road with different range of longitudinal slope classes and without any lateral slope. The logging operation was performed by the whole stem method where the stems were skidded to the roadside landings by a farm tractor after the trees were felled, delimbed and topped at the stump area.

Technical features of the tractor. A Massey Ferguson 285 farm tractor was employed in logging operations. This tractor was used for skidding operations and it has a backlift system. During the skidding operation, one end of the log was elevated on the back- lift system while the other end is skidded on the skid road surface (figure 2). The tractor was equipped with a cab to protect and minimize noise level for the operator. The rear tires were larger than the front tires in width and in diameter. The dimension num-

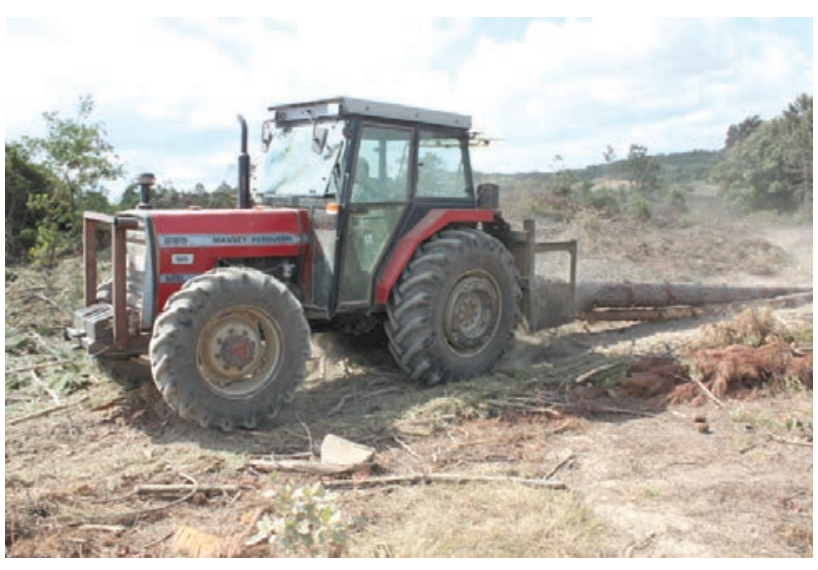

Figure 2. Skidding logs by farm tractor. Arrastre de troncos por tractor agrícola. bers of front and rear tires were 12.4-24PR12 and 18.430PR14, respectively. The width of the rear tires was 30 $\mathrm{cm}$ and their air pressure was 16 psi. The main technical features of the tractor were shown in table 1.

Data collection. A skid road, $2.5 \mathrm{~m}$ wide and $230 \mathrm{~m}$ long with upslope skidding direction, was selected for the study. The skid road passed through the stand in the eastwest direction and it has been used intensely this year. The longitudinal profile showed that the slope of the skid road ranged from 2 to 8 . The average length and the large end diameter of the skidded stems were $16 \mathrm{~m}$ and $32 \mathrm{~cm}$, respectively. The dimensions of every skidded log were measured with a steel tape and a compass. The number of skidded timber was changed between 1 and 3 .

Soil disturbances on skid roads during a log skidding operation by a farm tractor were measured in terms of soil displacement and rut depth formation. Field measurements were made at 12 cross sections at $15 \mathrm{~m}$ intervals along the skid roads. The soil displacement that emerged on the skid road was calculated based on the deformation areas on each cross section and the distance between cross sections. On the cross section along the skid road, soil displacement and rutting were examined and recorded for various numbers of tractor passes $\left(5^{\text {th }}, 10^{\text {th }}, 15^{\text {th }}, 20^{\text {th }}\right.$ and $30^{\text {th }}$ passes) (figure 3). Rutting was observed after the fifth passes because the soil type on the skid road was hard and sandy.

Deformation dimensions on skid roads were measured with a steel tape and a ruler. The distance between cross sections was measured by using measuring wheel. Each cross section shape was measured on the skid road. Then, the slopes of the cross section were written in AutoCad program. The soil displacement area was calculated for each cross section. Soil moisture content was measured through a hygrometer. The type of hygrometer used is TFA combi-tester. Measurement of soil moisture content was done at soil depth between $0-15 \mathrm{~cm}$. The effects of skidding on the skid road surface soil layer $(0-10 \mathrm{~cm}$

Table 1. Technical specifications of the tractor.

Las especificaciones técnicamente de un tractor.

\begin{tabular}{ll}
\hline \multicolumn{1}{c}{ Technical features } & \multicolumn{1}{c}{ Specifications } \\
\hline Brand & Massey Ferguson 285 \\
Motor power & $82 \mathrm{HP}$ \\
Motor type & Perkins \\
Cylinder number & 4 \\
Cylinder volume & 4.06 liter \\
Max. torque & 1,400 revolution per min. \\
Max. revolution (unload) & 2,160 revolution per min. \\
Weight & $3,470 \mathrm{~kg}$ \\
\hline
\end{tabular}


depth) have measuring (weight, texture and $\mathrm{pH}$ ) and soil mixture (sand, silt and clay), comparing these results with the respective values in samples taken from an undisturbed area (forest area). Soil samples were collected either on the skid road or forest land. Soil samples were taken after the

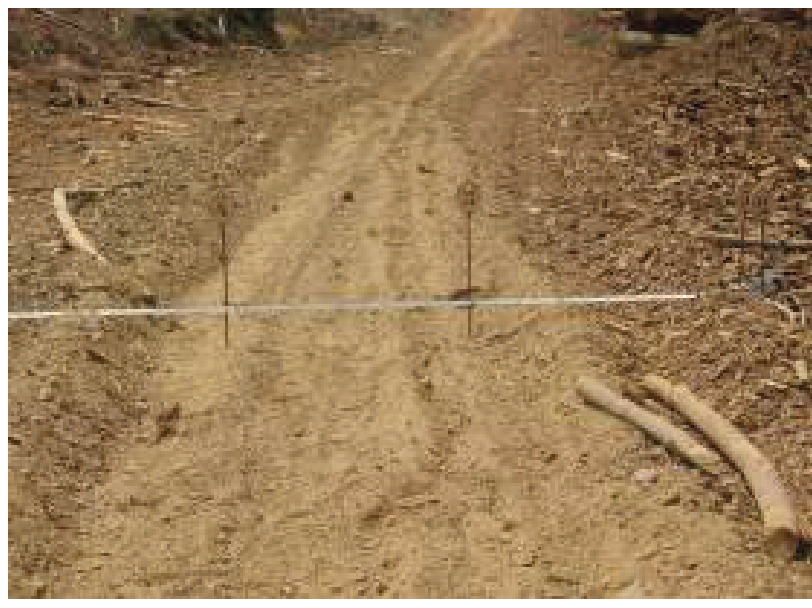

Figure 3. Field measurement points on cross section.

Puntos de las mediciones en la sección transversal de la vía. passing of the tractors. Soil samples were collected with the help of cylinders (diameter $5.5 \mathrm{~cm}$, length $5 \mathrm{~cm}$ ) and a soil hammer. All samples collected were put in plastic bags and labelled in this study area. The samples were brought to the laboratory where they were weighed and afterwards oven dried at $105{ }^{\circ} \mathrm{C}$ for $24 \mathrm{~h}$ and weighed for a second time. Volume weight, fine soil weight $(<2 \mathrm{~mm})$ and stone weight (> $2 \mathrm{~mm}$ ) (Gulcur 1974), soil texture (Karaoz 1992) and pH (Mc Lean 1982) were analyzed. The average values were compared with Mann-Whitney $U$ test in one of the nonparametric methods (Kalıpsiz 1981, Ozdamar 2002, Senol 2004).

\section{RESULTS}

In this study, as shown in table 2, the total volume of soil displacement for $230 \mathrm{~m}$ skid road was found to be $16.18 \mathrm{~m}^{3}$. The average deformation area for the cross sections and average volume of soil displacement between cross sections were found to be $0.061 \mathrm{~m}^{2}$ and $1.01 \mathrm{~m}^{3}$, respectively. Results revealed that the amount of soil deformation was generally higher at the center of the skid roads as compared to the control points at the edge of skid road (figure 4) and the rut depth was increased in accordance with the number of tractor passes (figure 5).

Table 2. Amount of soil displacement along skid road.

Nivel de perturbación del suelo a lo largo de una vía de saca.

\begin{tabular}{lccc}
\hline Cross sections & $\begin{array}{c}\text { Deformation area } \\
\text { in cross section }\end{array}$ & $\begin{array}{c}\text { Average deformation } \\
\text { area in cross section }\end{array}$ & $\begin{array}{c}\text { Distance between } \\
\text { cross sections }\end{array}$ \\
\cline { 2 - 4 } & $\left(\mathrm{m}^{2}\right)$ & $\left(\mathrm{m}^{2}\right)$ & $(\mathrm{m})$ \\
\hline Average & 0.0638 & 0.0606 & 14.38 \\
Max. & 0.1458 & 0.121 & 20.00 \\
Min. & 0.0343 & 0.035 & 10.00 \\
Std. Dev. & 0.0297 & 0.024 & 4.81 \\
\hline
\end{tabular}

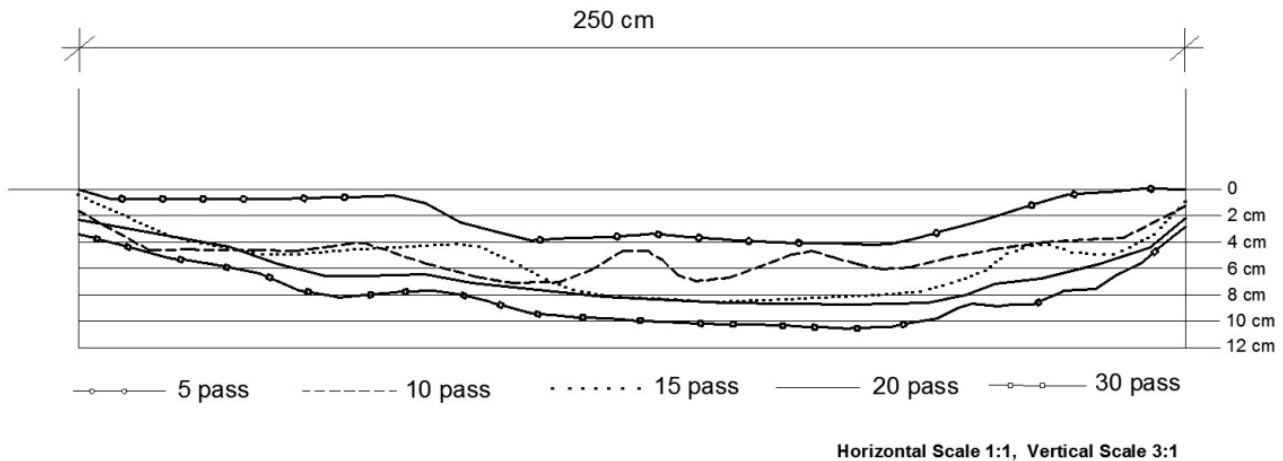

Figure 4. Average rut depth changes on sample cross sections.

Variaciones de la profundidad de la huella en una sección transversal. 
Soil properties were analyzed based on the soil samples collected from the skid road and the forest site (table 3). Results indicated that there was no important difference between the skid road and the forest site regarding volume weight, fine soil weight and soil texture values; however, stone weight was higher on the skid road samples than on that of the forest site due to soil displacement along skid road. In this study, as statistics between these average values, no difference was found when the soil features of skid road and forest site were compared.

\section{DISCUSSION}

Results indicated that soil displacement increased as the number of passes increased. In a similar study conducted by Najafi et al. (2010), it was reported that the amount of soil displacement increased with the number of passes. During the initial passes, the soils especially on the center

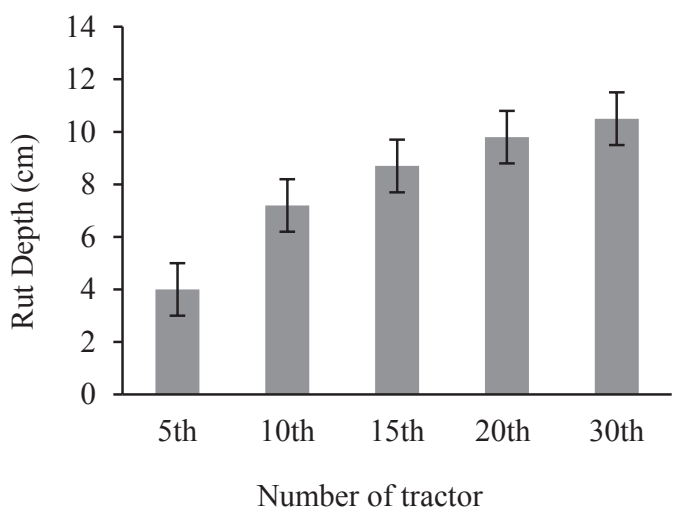

Figure 5. Rut depth variation on skid road during skidding.

Variaciones de la profundidad de la huella en las vías de saca durante del arrastre. of the skid road became very dusty, and then dusty ground was removed from the skid roads due to many factors such as wind, rainfall and operating vehicles. Thus, deep gully formations occurred in this section in the following passes. This process led to soil displacement and gully formations on the skid roads which potentially increased the risk of erosion (Pierzchala et al. 2014). Dobek et al. (2011) also reported that the development of gullies related to skidding operations causes runoff concentration along the skidding roads which may lead to the erosion processes.

Results revealed that the amount of soil deformation was generally higher at the center of skid roads compared to the control points at the edge of skid roads. Similar to previous studies, the rut depths on skid roads changed mainly depending on the number of passes (Alexander 2012). The rut depth was increased during the first five passes on this skid road. Afterwards, the rut depth decreased as the number of passes increased.

In a similar study, Erdas (1993) concluded the average rut depth is $10-15 \mathrm{~cm}$ after 10-20 tractor passes during a log skidding operation. In terms of slope variation on skid roads, results suggested that there was no considerable change on rut for different slope classes. With regards to this, Naghdi et al. (2009) also reported that maximum rutting depth for a rubber tire skidder was $22 \mathrm{~cm}$ after 20 passes. They also indicated that there was no significant correlation between the rut depth and the different classification of longitudinal slope. Some studies reported that one of the critical factors affecting the degree of soil compaction is the number of machine passes over a specific point (Majnounian and Jourgholami 2013). Most compaction occurs during the first ten passes of a vehicle with most of them occurring in the first three passes. Subsequent passes generally have little additional effects (Ampoorter et al. 2007). The major soil disturbance usually occurs during the first passes of machinery and increases with the number of passes (Gayoso and Iroume 1991). Most compaction occurs after the initial few passes (Matangaran and Kobayashi 1999).

Table 3. Soil characteristics on skid road and forest area (Mann-Whitney $\mathrm{U}, P<0.01$ ).

Características del suelo en el camino de saca y la superficie forestal.

\begin{tabular}{lrrrrrr}
\hline \multirow{2}{*}{ Soil properties } & \multicolumn{3}{c}{ Skid road } & \multicolumn{3}{c}{ Forest site } \\
\cline { 2 - 7 } & \multicolumn{1}{c}{ Mean } & \multicolumn{1}{c}{ Min. } & Max & Mean & \multicolumn{1}{c}{ Min. } & Max \\
\hline Volume weight $\left(\mathrm{g} \mathrm{L}^{-1}\right)$ & $1112.2^{\mathrm{a}}$ & 787.3 & 1587.8 & $1098.7^{\mathrm{a}}$ & 564.8 & 1523.4 \\
Fine soil weight $\left(\mathrm{g} \mathrm{L}^{-1}\right)$ & $968.7^{\mathrm{a}}$ & 606.1 & 1382.7 & $986.3^{\mathrm{a}}$ & 542.4 & 1348.8 \\
Stone weight $\left(\mathrm{g} \mathrm{L}^{-1}\right)$ & $143.5^{\mathrm{a}}$ & 10.0 & 680.3 & $112.5^{\mathrm{a}}$ & 5.8 & 548.8 \\
Sand (\%) & $66.0^{\mathrm{a}}$ & 46.7 & 77.8 & $65.5^{\mathrm{a}}$ & 30.6 & 87.8 \\
Silt (\%) & $12.0^{\mathrm{a}}$ & 4.5 & 28.0 & $13.1^{\mathrm{a}}$ & 3.5 & 30.8 \\
Clay (\%) & $22.0^{\mathrm{a}}$ & 9.6 & 47.4 & $21.4^{\mathrm{a}}$ & 8.8 & 52.1 \\
$\mathrm{pH}$ & $4.9^{\mathrm{a}}$ & 4.2 & 6.1 & $5.0^{\mathrm{a}}$ & 4.2 & 6.2 \\
\hline
\end{tabular}




\section{CONCLUSIONS}

In this study, soil displacement and rutting on the skid roads during a logging operation were investigated by field measurements after each pass of a farm tractor along the skid road. The study showed that the vehicle passes had a significant effect on soil displacement and rutting. Soil disturbance and rutting from skidding operations are common consequences of soil damage on skid road. Especially, the rutting causes serious erosion problems during heavy rainfalls. After heavy winter conditions and spring rains, erosive power of the surface run-off can create damages on the skid roads.

Skidding operations should be planned to minimize rutting. Furthermore, the appropriate machine types and machine sizes should be selected for skidding operations to minimize soil disturbance. In plantation areas, skid roads should be rehabilitated by a bulldozer and a grader. Thus, the risk of erosion is reduced in the years ahead.

\section{REFERENCES}

Akay AE, O Erdas. 2007. Estimating rut depth during skidding with a rubber-tired skidder. Suleyman Demirel University. Journal of Faculty of Forestry A(1): 49-57.

Akay AE, A Yuksel, M Reis, A Tutus. 2007. The impacts of ground-based logging equipment on forest soil. Polish Journal of Environmental Studies 16(3): 371-376.

Alexander AB. 2012. Soil compaction on skid trails after selective logging in moist evergreen forest of Ghana. Agriculture and Biology Journal of North America 3(6): 262-264.

Ampoorter E, R Goris, WM Cornelis, K Verheyen. 2007. Impact of mechanized logging on compaction status of sandy forest soils. Forest Ecology and Management 241: 162-174.

Ares A, TA Terry, RE Miller, HW Anderson, BL Flawing. 2005. Ground-based forest harvesting effects on soil physical properties and Douglas-Fir growth. Soil Science of American Journal 69: 1822-1832.

Dobek K, P Demczuk, J Rodzik, B Hołub. 2011. Types of gullies and conditions of their development in silvicultural loess catchment (Szczebrzeszyn Roztocze region, SE Poland). Landform Analysis 17: 39-42.

Erdas O. 1993. The effects of using skidders logging operations on mechanical properties of the soil and their biological consequences. Turkish Journal of Agricultural and Forestry 17: 1-10.

Gayoso J, A Iroume. 1991. Compaction and soil disturbances from logging in Southern Chile. Annals of Forest Science 48: 63-71.

Greene WD, WB Stuart. 1985. Skidder and tire size effects on soil compaction. South Journal of Applied Forestry 9(3): 15-17.

Gulcur F. 1974. Soil Physical and Chemical Analysis Methods. Istanbul, Turkey. Publications of Istanbul University, Faculty of Forestry No: 1970. 225 p.
Jamshidi R, D Jaeger, N Raafatnia, M Tabari. 2008. Influence of two ground-based skidding systems on soil compaction under different slope and gradient conditions. International Journal of Forest Engineering 19(1): 9-16.

Jakobsen BF, EL Greaceri. 1985. Compaction of sandy forest soils by forwarder operations. Soil and Tillage Research 5(1): 55-70.

Kalıpsız A. 1981. Statistical Methods. Istanbul, Turkey. Publications of Istanbul University, Faculty of Forestry No: 2837. $558 \mathrm{p}$.

Karaoz O. 1992. Toprakların Su Ekonomisine İlişkin Bazı Fiziksel Özelliklerinin Laboratuarda Belirlenmesi Yöntemleri. I.U. Orman Fakultesi Dergisi B39(2): 133-144.

Labelle ER, D Jaeger. 2011. Soil compaction caused by cut to length forest operations and possible short term natural rehabilitation of soil density. Soil Science Society American Journal 75(6): 2314-2329.

Lotfalian M, A Parsakhoo. 2009. Investigation of forest soil disturbance caused by rubber-tired skidder traffic. International Journal of Natural and Engineering Sciences 3(1): 79-82.

Majnounian B, M Jourgholami. 2013. Effects of rubber-tired cable skidder on soil compaction in Hyrcanian Forest. Croatian Journal of Forest Engineering 34(1): 123-135.

Matangaran JR, H Kobayashi. 1999. The effect of tractor logging on forest soil compaction and growth of Shorea selanica seedlings in Indonesia. Journal of Forestry Research 4: 13-15.

Mc Lean EO. 1982. Soil pH and lime requirement. In Page AL, RH Miller, DR Keeney eds. Methods of soil Analysis. Part 2. Chemical and Microbiological Properties. Second Edition. Wisconsin, USA. Soil Science Society of America Inc. Madison. p. 159-224.

Naghdi R, I Bagheri, M Lotfalian, B Setodeh. 2009. Rutting and soil displacement caused by 450C Timber Jack wheeled skidder (Asalem forest northern Iran). Journal of Forest Science 53: 314-319.

Najafi A, A Solgi, SHR Sadeghi. 2010. Effects of skid trail slope and ground skidding on soil disturbance. Caspian Journal of Environmental Science 8: 13-23.

Ozdamar K. 2002. Statistics and data analysis package programs. Istanbul, Turkey. Kaan Publishers. p. 135-155.

Pierzchala M, B Talbot, R Astrup. 2004. Estimating Soil Displacement from Timber Extraction Trails in Steep Terrain: Application of an Unmanned Aircraft for 3D Modelling. Forests 5: 1212-1223.

Schnurr-Pütz S, E Baath, G Guggenberger, HL Drake, K Küsel. 2006. Compaction of forest soil by logging machinery favors occurrence of prokaryotes. FEMS Microbial Ecology 58(3): 503-516.

Senol S. 2004. Non-parametric statistical methods. Smyrna, Turkey. Publications of Ege University, Faculty of Science No: 190. 285 p.

Sudherland BJ. 2003. Preventing soil compaction and rutting in the boreal Forest of Western Canada. FERIC. Advantage 4(7): 7-8.

Susnjar M, D Horvat, J Seselj. 2006. Soil compaction in timber skidding in winter conditions. Croatian Journal of Forest Engineering 27(1): 3-15. 